\title{
PREVALENCE OF BLAD AND CVM IN HOLSTEIN DAIRY CATTLE INTRODUCED TO MOROCCO
}

\author{
Ismaïl Boujenane and Karima Ouhmama \\ Department of Animal Production and Biotechnology, Institut Agronomique et \\ Vétérinaire Hassan II, PO Box 6202 Rabat-Instituts, 10101 Rabat, Morocco
}

\section{SUMMARY}

The aim of this work was the estimation of BLAD and CVM prevalence in Holstein heifers and bulls that produced the semen introduced to Morocco. The study was carried out on 1874 heifers imported from France, Germany and Netherlands between 2005 and 2006 and 221 bulls that produced the semen imported from Canada, USA and France between 1999 and 2007. Based on the genotypes of sires and maternal grandsires mentioned on heifers' pedigrees, $2.1 \%$ and $17.5 \%$ of heifers introduced to Morocco were potential BLAD and CVM carriers, respectively. No bull that produced the semen was BLAD-carrier, whereas $0.5 \%$ bulls were CVM carriers. The frequency of at risk matings, i.e. those between potential carrier heifers and known carrier bulls, was 0 for BLAD and $0.7 \%$ for CVM. The frequency of mating between non-carrier heifers and confirmed carrier bulls was $0.2 \%$ and $16.8 \%$ for $B L A D$ and $C V M$, respectively. The BLAD and CVM allele frequencies in heifers varied from 0.01 to 0.12 and from 0.03 to 0.14 , respectively. It was concluded that a surveillance programme should be implemented in Morocco in order to avoid the introduction and the dissemination of farm animal hereditary defects.

Keywords: heifers, bulls, semen, Holstein, genetic defect, BLAD, CVM, at risk mating

\section{INTRODUCTION}

The Moroccan Holstein population was mainly constituted through the importation of pregnant heifers from European and North-American countries. Between 1982 and 2000, 273346 heifers were introduced, averaging 13667 heifers per year (Boujenane, 2002). After the apparition of Bovine Spongiform Encephalopathy (BSE) in some European countries, these importations were suspended from November 2000 to October 2004, but started again in October 2004. The importation of dairy cattle was governed by a law that lays down the minimum performances of heifers' ancestry, without paying attention to genetic defects. On the other hand, the BLAD (bovine leukocyte adhesion deficiency) and the CVM (complex vertebral malformation). Both BLAD and CVM are manifested in the presence of the homozygous recessive allele and have reported in Holstein cattle (Shuster et al., 1992; Tajima et al., 1993; Agerholm et al., 2001 and Nagahata, 2004) of exporting countries to Morocco. Since the Moroccan Holstein population was constituted through heavy importations of heifers, it is probable that some heifers or semen carrying these defects were introduced to the country.

Issued by The Egyptian Society of Animal Production 
The objectives of this study were to analyse the pedigrees of heifers and bulls that produced the semen in order to determine the BLAD and CVM prevalence and to estimate the BLAD and CVM allele frequencies in imported Holstein cattle.

\section{MATERIALS AND METHODS}

The study of BLAD and CVM prevalence in Holstein cattle was carried out based on two types of data:

- Data concerning heifers introduced between 2005 and 2006. They were obtained from pedigrees available at the Direction of Control and Quality of Casablanca port.

- Data concerning bulls that produced the proven semen introduced and used in Morocco between 1999 and 2007. They were obtained from pedigrees available at the Casablanca Artificial Insemination Centre.

The information collected for each heifer was:

- Identification number and birth date of heifer

- Identification number and birth date of sire

- BLAD status of sire (BL: BLAD-carrier; TL: BLAD non-carrier)

- CVM status of sire (CV: CVM-carrier; TV: CVM non-carrier)

- Identification number and birth date of dam

- Identification number of maternal grandsire

- BLAD status of maternal grandsire (BL: BLAD-carrier; TL: BLAD non-carrier)

- CVM status of maternal grandsire (CV: CVM-carrier; TV: CVM non-carrier)

- Identification number and birth date of AI bull

- BLAD status of AI bull (BL: BLAD-carrier; TL: BLAD non-carrier)

- CVM status of AI bull (CV: CVM-carrier; TV: CVM non-carrier)

Concerning bulls that produced the imported semen, information collected from pedigrees were:

- Identification number and birth date of bull

- BLAD status of bull (BL: BLAD-carrier; TL: BLAD non-carrier)

- CVM status of bull (CV: CVM-carrier; TV: CVM non-carrier)

- Number of straws of semen introduced to Morocco

- Arrival date and bull's origin country.

The BLAD and CVM statuses of imported heifers were not mentioned on their pedigrees. Therefore, they were indirectly inferred, with a certain probability, from those of their male parents, since the BLAD and the CVM statuses of their sires and maternal grandsires were mentioned on the heifers' pedigrees. Based on this information, a heifer was considered as a potential carrier when her sire and/or her maternal grandsire were determined as being carriers. She was considered as noncarrier when both her sire and maternal grandsire were determined as being noncarriers. The status of the heifer was determined with the assumption that the maternal grand-dam was a non-carrier. Concerning the bulls that produced the imported proven semen, the BLAD and the CVM statuses were mentioned on their pedigrees. Likewise, the genetic statuses of AI bulls were mentioned on the pedigrees of heifers that they inseminated. The frequency of BLAD and CVM alleles in the imported heifers' population was calculated as follows:

$$
B L A D \text { or CVM allele frequency }=1-\frac{2(A A)+(A a)}{2 N}
$$


where AA is the number of non-carrier heifers, Aa is the number of BLAD or CVM carrier heifers and $\mathrm{N}$ is the total number of heifers studied $(\mathrm{N}=1874)$. The number of carrier heifers was calculated using the probability of matings between parents of various genetic statuses according to Durand (2002) and the number of cases present in the sample.

\section{RESULTS}

The sample studied included 1874 heifers imported from Germany (66.5\%), France (26\%) and Netherlands (7.5\%). The heifers imported during 2005 represented $36.8 \%$, with $25.9 \%$ from France, $9.8 \%$ from Germany and $1.1 \%$ from Netherlands. Those introduced during 2006 represented $63.2 \%$, with $56.7 \%$ from Germany, $6.4 \%$ from Netherlands and $0.1 \%$ from France.

From 1999 to 2007, 182747 straws of semen produced from 221 Holstein bulls were imported, averaging 29287 straws per year. This number varied from 4167 straws during 2000 to 72507 straws during 2006. These straws of semen were imported from Canada (57\%), USA (34\%) and France (9\%). Furthermore, the number of straws per bull averaged 827 , varying from 10 to 8010 straws.

The analysis of pedigree information of bulls that produced the semen imported between 1999 and 2007 showed that none was BLAD-carrier but $0.5 \%$ of them were CVM carriers. This semen was imported from Canada.

Among the imported heifers, $0.2 \%$ and $2 \%$ were inseminated by semen produced from BLAD and CVM carrier bulls, respectively.

The proportion of potential BLAD-carrier heifers (i.e. sires and/or maternal grandsires were known carriers) was $2.1 \%$ of all heifers studied (Table 1). Among these heifers, $0.3 \%$ had only the sire determined as being carrier, $1.6 \%$ had only the maternal grandsire determined as being carrier, and $0.2 \%$ had both the sire and the maternal grandsire determined as being carriers. The potential BLAD-carrier heifers imported from France, Netherlands and Germany represented 5.1\%, 2.1\% and 0.9\%, respectively of those imported from each country. Likewise, the proportion of potential CVM-carrier heifers was $17.5 \%$ of all heifers studied (Table 1), where those imported from France, Netherlands and Germany represented 45.8\%, 27.9\% and $5.5 \%$, respectively of those imported from each country. Among the potential CVM carriers, $8.3 \%$ had only the sire determined as being carrier, $8.2 \%$ had only the maternal grandsire determined as being carrier, and $1 \%$ had both the sire and the maternal grandsire determined as being carriers.

Table 1. Frequency of potential BLAD or CVM carriers among the imported heifers $(\mathrm{N}=1874)$.

\begin{tabular}{lcccc}
\hline Potential carrier heifer through & \multicolumn{2}{c}{ BLAD } & \multicolumn{2}{c}{ CVM } \\
\hline Carrier sire & $\mathrm{N}$ & $\begin{array}{c}\text { Frequency } \\
(\%)\end{array}$ & $\mathrm{N}$ & $\begin{array}{c}\text { Frequency } \\
(\%)\end{array}$ \\
Carrier maternal grand-sire & 6 & 0.3 & 157 & 8.3 \\
Carrier sire and carrier maternal grandsire & 3 & 0.2 & 17 & 1,0 \\
\hline Total & 39 & 2.1 & 328 & 17.5 \\
\hline
\end{tabular}


Using Durand's probabilities, the proportion of imported heifers determined as being BLAD carriers varied from $0.6 \%$ when their maternal grand-dams were assumed to be non-carriers to $25.2 \%$ when these grand-dams were confirmed carriers. Consequently, the BLAD allele frequency would vary from 0.01 to 0.12 . Likewise, the proportion of heifers determined as being CVM carriers varied from $6.8 \%$ when their maternal grand-dams were assumed to be non-carriers to $28.8 \%$ when these were confirmed carriers. Consequently, the CVM allele frequency would vary from 0.03 to 0.14 .

The status of mating with regards to BLAD and CVM genotypes of imported heifers and AI bulls showed that the frequency of matings between potential carrier heifers and known carrier AI bulls (i.e. at risk matings) was nil for BLAD and $0.7 \%$ for CVM (Tables 2 and 3). The frequency of matings between non-carrier heifers and carrier AI bulls was $0.2 \%$ for BLAD and $1.3 \%$ for CVM. In addition, $2.1 \%$ and $16.8 \%$ of matings were between non-carrier AI bulls and potential carrier heifers for BLAD and CVM, respectively. Finally, $97.7 \%$ of matings occurred between BLAD non-carrier animals and $81.2 \%$ between CVM non-carrier animals.

Table 2. Frequency (\%) of matings for various BLAD statuses $(\mathrm{N}=1874)$

\begin{tabular}{lccc}
\hline & \multirow{2}{*}{ BLAD status } & \multicolumn{2}{c}{ Heifer } \\
\cline { 3 - 4 } Bull & Carrier & 0 & Non-carrier \\
& Non-carrier & 2.1 & 0.2 \\
& & & 97.7 \\
\hline
\end{tabular}

Table 3. Frequency (\%) of matings for various CVM statuses $(\mathrm{N}=1874)$

\begin{tabular}{llcc}
\hline \multirow{2}{*}{ CVM status } & \multicolumn{2}{c}{ Heifer } \\
\cline { 3 - 4 } & Carrier & Potential carrier & Non-carrier \\
\hline \multirow{3}{*}{ Bull } & Non-carrier & 0.7 & 1.3 \\
\hline
\end{tabular}

\section{DISCUSSION}

None of bulls that produced the semen imported between 1999 and 2007 was BLAD-carrier. This may be explained by the DNA testing made available since 1991 (Tajima et al. 1993), allowing BLAD-free bulls only to be progeny tested (Boujenane, 2007). This indicates that the dissemination of BLAD through the use of semen was almost impossible, because the introduction of proven semen to Morocco started 8 years after the development of DNA testing. However, $0.5 \%$ of bulls were CVM carriers, i.e. expectedly one bull out of the 211 bulls that produced semen imported and used in Morocco between 1999 and 2007. Furthermore, 180 straws of semen of the CVM-carrier bull were imported. If all these straws were used successfully to give birth to calves, there would be $90 \mathrm{CVM}$-carrier calves born from this sire. In addition, the DNA testing for CVM was developed in 2001 (Agerholm et al., 2001). This means that semen from some CVM-carrier bulls have been used for AI between 1999 and 2001 without being identified. 
Among the heifers studied, 2.1\% were potential BLAD-carriers and $17 \%$ were potential CVM-carriers. This difference is due to the fact that CVM is a relatively recent disease compared to BLAD, and some sires of imported heifers have been used for artificial insemination even though they were determined later as being CVM carriers. The Holstein cattle have been genotyped for these mutations in several countries. Thus, the frequency of BLAD-carrier prevalence was $13.4 \%$ in Danish Holstein-Friesian cattle (Jorgensen et al., 1993), 8.1\% in Japanese Holstein animals (Nagahata et al., 1997) and 5.7\% in Brazilian Holstein cows (Ribeiro et al., 2000). Shuster et al. (1992) reported a heterozygote frequency of $14.1 \%$ for bulls and $5.8 \%$ for cows in American Holstein. In Sweden, 23\% of all Holstein bulls born between 1995 and 1999 were confirmed CVM carriers (Berglund et al., 2004). In France, Malher et al. (2006) estimated that the frequency of CVM carriers was roughly about $10-12 \%$ in Holstein cattle of Brittany. These results indicate that these mutations are prevalent among Holstein cattle throughout the world.

The frequency of BLAD and CVM carriers in the Holstein cattle of Morocco is probably higher than that found in this study. In fact, the importation of heifers from Europe was heavy during the 1990's, i.e. when these diseases were highly present in Holstein cattle. The stoppage of heifers' importation between 2000 and 2004 in order to avoid the introduction of BSE disease to the country had at the same time limited the introduction of BLAD and CVM genes. Otherwise the frequency of these diseases, especially the CVM, would be greater than the current frequency.

The frequency of at risk matings, i.e. between confirmed carrier AI bulls and potential carrier heifers, was nil for BLAD and 0.7\% for CVM. In France, Malher et al. (2006) found that incidence of matings between CVM gene carriers, between a carrier bull and a non-carrier cow and between a non-carrier bull and a carrier cow were estimated to be $1.4,10.6$ and $9 \%$, respectively, and $1.1,9.3$ and $10.9 \%$, respectively in heifers. In Morocco, Baqasse (1999) reported that the rate of abortions among the imported heifers was $6.7 \%$. Since the abortion is one symptom of these diseases, a part of the observed abortions may result from these diseases. Likewise, Durand (2002) showed that daughters of carrier sires which were inseminated by semen of carrier bulls gave birth to $0.4 \%$ calves less than matings occurring between non-carrier animals.

Some heifers considered as non carriers, on the basis of BLAD and CVM statuses of their sires and maternal grandsires, may be determined as being carriers through their maternal grand-dams. Therefore, the frequency of at risk matings would be higher than the frequency reported in this study. Durand (2002) considered as at risk mating, any mating between a carrier bull and a non-carrier heifer. Thus, matings between non-carrier bulls and potential carrier heifers on one hand, and matings between carrier bulls and non- carrier heifers on the other hand might give birth to heterozygous calves, which could later disseminate BLAD and CVM genes in the population.

The BLAD and CVM allele frequencies in the present study were high, indicating that the eradication of these alleles in the Moroccan Holstein population will take several years. The frequencies found in this study are in the range of those reported elsewhere. The frequency of BLAD allele was 0.028 in Holstein cows in Brazil (Ribeiro et al., 2000) and from 0.041 to 0.054 in some Holstein herds in Japan (Nagahata et al., 1997). Rusc and Kaminski (2007) reported that the frequency of CVM allele averaged 0.12 in Polish Holstein-Friesian bulls active in 2001-2005. In 
France, Malher et al. (2006) estimated that the frequency of CVM allele was 0.050.06 .

\section{CONCLUSION}

The pedigree-analysis showed the presence of BLAD and CVM alleles in the imported Holstein heifers. Since these diseases are economically important, Moroccan dairy farmers should avoid the use of proven semen from carrier bulls on one hand and the importation of heifers sired by carriers on the other hand. In addition, it is essential to implement a surveillance programme in order to avoid the introduction and the dissemination of genetic defects of farm animals.

\section{ACKNOWLEDGEMENTS}

We would like to thank the Direction of Control and Quality of Casablanca port and the Casablanca AI Centre which provided us with pedigrees of animals.

\section{REFERENCES}

Agerholm, J.S., C. Bendixen, O. Andersen, J. Arnbjerg, 2001. Complex vertebral malformation in Holstein calves. J. Vet. Diagn. Invest., 13: 283-289.

Baqasse, M., 1999. Evaluation de l'opération d'importation des génisses laitières : Devenir et performances. Mémoire ${ }^{\text {ème }}$ Cycle Agronomie, I.A.V. Hassan II, Rabat, Morocco. $120 \mathrm{pp}$.

Berglund, B., A. Persson and H. Stalhammar, 2004. Effects of complex vertebral malformation on fertility in Swedish Holstein cattle. Acta Vet. Scand., 45: 161165 .

Boujenane, I., 2002. Les races bovines au Maroc. Rabat, Morocco : Actes Editions. $144 \mathrm{pp}$.

Boujenane, I., 2007. Les anomalies héréditaires chez les bovins laitiers. L'Espace Vétérinaire, 72: 7-8.

Durand, V., 2002. Incidence des retours associés à l'affection génétique «Complexe de malformation vertébrale » en race Holstein. Thèse de Doctorat Vétérinaire, ENV Nantes, France. 160 pp.

Jorgensen, C.B., J.S. Agerholm, J. Pedersen and P.D. Thomsen, 1993. Bovine leukocyte adhesion deficiency in Danish Holstein-Friesian cattle. I. PCR screening and allele frequency estimation. Acta Vet. Scand., 34: 231-236.

Malher, X., F. Beaudeau and J.M. Philipot, 2006. Effects of sire and dam genotype for complex vertebral malformation (CVM) on risk of return-to-service in Holstein dairy cows and heifers. Theriogenology, 65: 1215-1225.

Nagahata, H., 2004. Bovine leukocyte adhesion deficiency (BLAD): A review. J. Vet. Med. Sci., 66: 1475-1482.

Nagahata, H., T. Miura, K. Tagaki, M. Ohtake, H. Noda, T. Yasudaand K. Nioka, 1997. Prevalence and allele frequency estimation of bovine leukocyte adhesion deficiency (BLAD) in Holstein-Friesian cattle in Japan. J. Vet. Med. Sci., 59: 233238. 
Ribeiro, L.A., E.E. Baron, M.L. Martinez and L.L. Coutinho, 2000. PCR screening and allele frequency estimation of bovine leukocyte adhesion deficiency in Holstein and Gir cattle in Brazil. Genet. Mol. Biol., 23: 831-834.

Rusc, A., and S. Kaminski, 2007. Prevalence of complex vertebral malformation carriers among Polish Holstein-Friesian bulls. J. Appl. Genet., 48: 247-252.

Shuster, D.A., M.E. Kehrli, M.R. Ackermann and R.O. Gilbert, 1992. Identification and prevalence of a genetic defect that causes leukocyte adhesion deficiency in Holstein cattle. Proc. Natl. Acad. Sci. U.S.A., 89: 9225-9229.

Tajima, M., M. Irie, R. Kirisawa, K. Hagiwara, T. Kurosawa and K. Takahashi, 1993. The detection of a mutation of CD18 gene in bovine leukocyte adhesion deficiency (BLAD). J. Vet. Med. Sci., 55: 145-146. 
ظهور بعض اللعيوب الخظقية الوراثية مثل الـ BLAD و CVM فى ماثية الهولسثين إسماعيل بوجينان، كريمة إوهماما قسم الإتتاج الحيوانس والتكنولوجيا الحيوية، معطج الحسن الثانسى للزراعة والبيطرية، الرياط، الدفرب

الهدف من الدراسة هو تقدير انتشارلى BLAD و CVM فى المجلات الهولسيثن و الذكور التى تنتج السائل

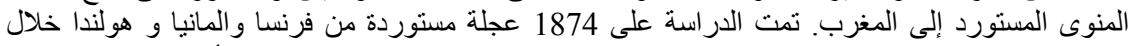

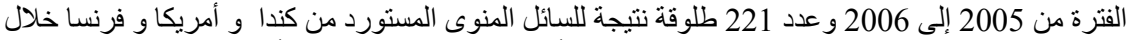

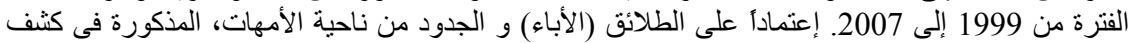

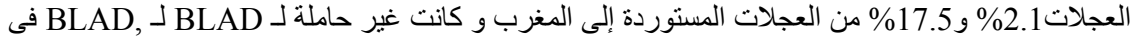

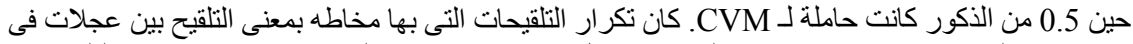

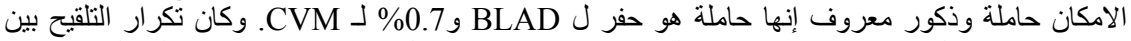

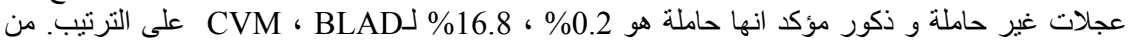
الدراسة جذورة إنشاء برنامج مراقبة فى المغرب كلى نتيجة إستخدام وإنتشار عيوب وراثية في حيو انات 